\title{
La traducción y la subtitulación en el aula de idiomas
}

\section{Translation and subtitling within the language classroom}

\section{Carolina Castro Moreno}

Fecha de recepción: 13/07/2020; Fecha de revisión: 16/09/2020; Fecha de aceptación: 11/02/2021

\section{Cómo citar este artículo:}

Castro Moreno, C. (2021). La traducción y la subtitulación en el aula de idiomas. Revista de Innovación y Buenas Prácticas Docentes, 10(1), 1-14.

\section{Autor de Correspondencia:192camoc@uco.es} \begin{abstract}
Resumen:
La traducción ha sido considerada como una actividad profesional centrada en un producto final, en lugar de como un medio para un fin determinado: la comunicación.

Sin embargo, esta interpretación olvida los innumerables beneficios que esta actividad ofrece. Siguiendo esto, el uso del subtitulado en la clase de lenguas es clave para la asimilación y mejora de contenidos lingüísticos mediante un aprendizaje que tiene en cuenta el contexto sociocultural de estos contenidos. $\boxminus$ subtitulado es crucial para ayudar al cerebro a visualizar simultáneamente el sonido y la traducción de un concepto, lo que, contrariamente a lo que se cree, permite a los estudiantes adquirir las estructuras apropiadas y omitir la traducción literal.

Siguiendo esto, el objetivo de este artículo es reevaluar el papel de la traducción y mostrar el potencial de los subtítulos en el ámbito de la enseñanza de lenguas mostrando su estrecha relación con los aspectos culturales y el aprendizaje de la lengua.

Así pues, la implementación de una unidad didáctica centrada en el uso del subtitulado ha mostrado la mejora en los resultados del alumnado en todas las destrezas de la lengua y, por tanto, ha evidenciado el impacto positivo de este recurso en el aula.
\end{abstract}

Palabras clave: cultura, enseñanza de lenguas, lenguas, nuevas tecnologías, traducción.

\section{Abstract:}

For many years, translation has not usually been regarded as a means to an end, namely, communication, but as a professional activity focussed on the product; thus, it clearly differs from the task implemented within the second language classroom.

However, this interpretation overlooks the myriad of benefits that this practice provides learners with. Furthermore, the use of subtitles within the language classroom is key to make learners assimilate and master language-related contents by considering their sociocultural context. Subtitles prove to be crucial to help the brain visualize the sound and the translation of a concept, which, contrary to what one might think, allows learners to acquire the appropriate structures and avoid literal translations.

Following this, the present paper aims at reassessing the role of the translation and showing the potential of subtitles within the language teaching arena by showcasing the close relationship between translation, subtitles, culture and learning.

Thus, the implementation of a didactic unit focused on the use of subtitling has shown the improvement in students' results in all language skills and, therefore, has shown the positive impact of this resource within the language classroom.

Key Words: culture, languages, language teaching, new technologies, pedagogical translation. 


\section{INTRODUCTION}

A common misconception found in the educational context is the association of translation with a professional activity. In this respect, it is essential to recognize the type of translation included within the language classroom, which, known as pedagogical translation, has, in fact, little or even nothing to do with professional translation.

Following this, the present paper aims at reassessing the role of the translation within the language teaching arena. Translation within the educational context would be based on the development of critical and reflective skills which, at any rate, would lead to the improvement of the second language taught and, as a result, would not be oriented to the use of translation to get a final product but as a means to an end. Therefore, its objective would be entirely didactic.

On a different level, translation has been disregarded on the assumption that good teaching cannot let room for the introduction of the mother tongue, considering it as damaging for the learning of the foreign language. What is arguable, however, is that this assumption overlooks the positive influence that the mother tongue brings in terms of language learning.

It is at this point when we must highlight the crucial role that subtitles may play within our classrooms. Nowadays, the screen is gaining ground among our society and therefore, it is becoming essential when it comes to language teaching. More and more students use original series and films to improve their knowledge of a second language but, to learn, they need to understand, at least, some of the information they are receiving. Consequently, taking advantage of subtitles may help them acquire the language in more life-like contexts of use. In this sense, the different types of subtitles that exist give learners and teachers the opportunity to exploit this resource depending on their specific language needs.

Based on these arguments, in this paper we will review literature focused on establishing the difference between pedagogical and professional translation, showing the benefits of pedagogical translation within the classroom and distinguishing the types of subtitles that exist.

To finish, it is necessary to conclude this section by giving a definition of two central concepts that shall be referred to throughout this paper, namely the concepts of $\mathrm{L} 1$, which would refer to the mother tongue of the speaker, and the L2, which would be related to the second or foreign language, in this case, English.

\section{DEVELOPMENT OF THE INNOVATION EXPERIENCE}

\subsection{Objectives}

The present paper aims at assessing the current role of translation and the use of subtitles within the language classroom so as to showcase the main benefits that these activities may entail. To such a view, it includes a didactic unit with different materials that have been implemented to assess the efficiency of subtitles. Hence, more specifically speaking, its main objectives may be presented as follows:

1. To portray the existing dissimilarities between professional and pedagogical translation with a view to understanding the assets that the latter may provide learners with;

2. To distinguish the different types of subtitles;

3. To highlight the benefits of the inclusion of subtitles when learning a foreign language.

4. To provide resources to implement subtitles within the classroom.

5. To check the potential of subtitling within the classroom by means of a didactic unit. 


\subsection{Pedagogical vs professional translation}

For many years, translation has been the bone of contention regarding whether or not it could be considered as a valid tool to be implemented within the language classroom.

Many practitioners have associated translation with an activity focused on a final product and the evoking emotions from its target readers or, in other words, a process which is focused on the creation of a perfectly polished text where the specific nuances of the source text remain so that it provokes the same responses in the recipients. Although this clearly constitutes part of a translation process, this is quite apart from the process intended to find its place within the language classroom.

Based on this, we may distinguish between two clearly differentiated types of translation, the first having been defined previously: professional translation. However, for practical purposes, our focus of study shall comprise the second type of translation, namely, pedagogical translation.

As its name suggests, this type of activity is undoubtedly linked to the language classroom and, more specifically to teaching pedagogy. Following De Arriba (1996), pedagogical translation constitutes an instrumental type of translation which has a didactic goal in that it is oriented to a limited audience: teachers and learners. It does not aim to reach a huge number of recipients and evoke profound feelings and emotions, but, on the contrary, it is centred on the comprehension and correct use of grammatical structures and the acquisition and perfection of the desired language (De Arriba, 1996).

The translated text, therefore, serves to make learners enhance their language proficiency level, whereas in professional translation the text represents the very goal of the process. As a result, the main objective of pedagogical translation is to make learners comprehend, rather than understand.

As De Arriba(1996, p. 278) states, the central objectives of pedagogical translation may be specified as follows:

- To encourage students in the sense that they would feel confident when using their L1; consequently, translation and the implementation of the L1 should be regarded as an unblocking tool;

- To perfect the L1 since translation offers students the possibility of reflecting upon their language in terms of vocabulary, idioms, fixed expressions and syntax;

- To improve both reading and writing comprehension and enlarge the amount of linguistic and lexical knowledge in the target language;

- To enhance the communicative production in the L2 owing to the impossibility of learners of leaving the L1 aside. As a result, using the L1 should be seen as a means to master the L2;

- And finally, to provide learners with mechanisms to compare linguistic systems and, as a result, to control interferences between languages.

Needless to say, although both types of translation share a point of reference, that being the transmission of concepts from one language into another, they both have their own specific and distinctive features; consequently, the different elements that shape the process of translation differ greatly depending on whether this activity is used with pedagogical purposes or not. 


\begin{tabular}{|c|c|c|}
\hline & Pedagogical Translation & Professional Translation \\
\hline Objectives & $\begin{array}{l}\text { It is a means to learn the } \\
\text { language, to control } \\
\text { comprehension and to explain } \\
\text { words or structures that may be } \\
\text { difficult to understand }\end{array}$ & $\begin{array}{l}\text { It is an end in itself, since its } \\
\text { purpose is that of transmitting a } \\
\text { message which should be } \\
\text { understood by its audience }\end{array}$ \\
\hline $\begin{array}{l}\text { Situation of } \\
\text { communication }\end{array}$ & $\begin{array}{l}\text { Translation takes place for the } \\
\text { teacher. Therefore, it is possible } \\
\text { to translate a produced text, } \\
\text { "neutralised", without a context }\end{array}$ & $\begin{array}{l}\text { Translation only takes place } \\
\text { when the parameters of the } \\
\text { situation are known: where } \\
\text { should the text appear? For } \\
\text { which type of readers is it } \\
\text { intended? }\end{array}$ \\
\hline $\begin{array}{c}\text { Nature of the translated } \\
\text { text }\end{array}$ & $\begin{array}{l}\text { Sometimes we translate without } \\
\text { understanding at all since the } \\
\text { purpose of the exercise partly } \\
\text { consists in checking this } \\
\text { understanding }\end{array}$ & $\begin{array}{l}\text { Translation is not possible if the } \\
\text { text is not perfectly understood }\end{array}$ \\
\hline Direction of translation & Version or theme & $\begin{array}{l}\text { It only occurs in the direction } \\
\text { language } 2 \longrightarrow \text { language } 1\end{array}$ \\
\hline
\end{tabular}

Figure 1. Pedagogical vs professional translation.

Source: Grellet (1991, p. 13) (in De Arriba, 1996, p. 276).

\subsection{Pedagogical translation in the language classroom}

Pintado (2012, p. 342-343) claims that the general rejection against the use of pedagogical translation revolves around the following statements:

- Pedagogical translation is not the objective of FL learning;

- It is totally opposite to the manner in which we naturally learn a language;

- It hinders students' thoughts in the foreign language;

- It is based on the form rather than on the content;

- It breaks the monolingualism aimed at the second language classroom;

- It is not communicative, natural, motivating or engaging;

- It provides a wrong conception of equivalence;

- It implies first language dependence and interference;

- It uses decontextualized texts which are not appropriate for students;

- It is a skill independent of those of reading, writing, listening and speaking;

- It does not bring advantages in class for it requires a vast knowledge of the language.

Figure 2. Arguments against pedagogical translation.

Source: Own elaboration.

Nevertheless, it has been already confirmed that the only thing all these arguments do is hide the true potential of this tool in terms of language acquisition and 
learning, and, as a result, following Pintado (2012, p. 343) and Witte et al. (2009, p. 3438 ), the following may be stated (Figure 3):

- Translation is a further approach in language learning;

- It is a communicative task since interlinguistic communication is a communicative act;

- In some cases, it is needed, especially for beginners, so as to help them understand what they are listening to;

- It requires accuracy;

- It allows students to practice subabilities and provides new experiences;

- It brings a wide range of benefits for the students since it constitutes a contrastive tasks which allow them to compare two languages and the way they work and differ; in other words, it develops interlanguage awareness;

- It promotes the students' ability to expand their lexicon;

- It implies a better comprehension of one's mother tongue and the culture behind it;

- It associates form with meaning;

- It uses authentic material;

- Translation provides an understanding of texts and consequently, of language, since it makes it necessary for the reader to develop deeper reading and comprehension strategies;

- On those occasions when translation is used as a cognitive tool, it can counteract the tendencies to transfer structures from the first language.

- Its analysis provides students with a more deep knowledge of the language and other positive aspects;

- Translation is an integrative resource which involves various obstacles in various levels of language. As a result it constitutes "an activity which is much closer to real life language use" (Witte et al., 2009, p. 38).

Figure 3. Arguments in support of translation.

Source: Own elaboration.

\subsection{New technologies within the classroom}

New technologies, and more specifically Information and Communication Technologies (ICTs), are becoming an essential tool within the classroom, facilitating students their language learning process.

More specifically, the effective use of all the resources available both inside and outside the classroom becomes one of the major objectives to attain in the learning process, since students should not forget that learning does not start and end in the classroom. On the contrary, the learning process is a cyclical process that goes beyond the classroom walls and that has to be present in any situation of the students' daily life.

To this respect, audiovisual materials and videos make students break from routine within the classroom, and provide plenty of real-life like communicative situations, up to date input material and realistic opportunities for output. By all means, however, 
they should be understood as a complementary resource that should be exploited together with the book.

Finally, learning and teaching with videos can deepen students' learning by supporting instructional objectives integrated in the classroom. However, it can be challenging to select the "best" technological tools and contents while not losing sight of the desired goals for students. In this sense, integrating those videos and tools shall unveil not only a challenge but also an eye-opening experience for both teachers and students.

\subsection{The power of subtitling within the language classroom}

Soler $(2017$, p. 168$)$ defines audiovisual translation as a variety of translation that appeared in the 1930s and which makes it possible the linguistic transfer of an audiovisual text. This practise implies the combination of two linguistic channels: the visual -through the use of images- and the verbal channel -by means of the use of words. Díaz-Cintas (2012, p. 102) also defines this practice as:

una práctica lingüística que consiste en ofrecer, generalmente en la parte inferior de la pantalla, un texto escrito que traduce los diálogos de los actores, así como de aquellos elementos discursivos que forman parte de la fotografía (cartas, pintadas, leyendas, pancartas, etc.) o de la pista sonora (canciones, voces en off, etc.) y que están codificados en otra lengua.

Following this, not only does the implementation of audiovisual materials and their translation provide exposure to nonverbal cultural elements, but it also deals with linguistic and cultural aspects of communication in real contexts of use (Díaz-Cintas, 2012).

The communicative approach, which is nowadays the backbone for the teaching of languages, is based on motivation, and implies the use of authentic materials, the promotion of oral comprehension activities and the recreation of real-life-like communicative contexts within the classroom. Hense, Díaz-Cintas (2012, p. 97) claims that, to achieve this goal, several teachers have tried to extrapolate real-life situations to the language classroom, which has made it necessary to implement audiovisual materials in the curriculum.

On the contrary, Díaz-Cintas (2012) claims that many scholars believe that the implementation of subtitling when learning a foreign language might lead to the deceleration of oral comprehension skills, the distraction of the learners and their dependence and passivity: since they can read what is said, they do not focus on the oral message.

However, subtitles do not constitute a negative element, but they can provide benefits precisely for those students who struggle with L2 understanding. The written text, consequently, help learners to keep the spoken message under observation, since it could not probably be completely understood without such written support (Talaván, 2011, p. 266).

In other words, subtitles within audiovisual material should be considered as a positive reinforcement for students since they contribute to arise security in students, contrary to what happens with unsubtitled audiovisual materials, which tend to create high levels of anxiety and insecurity among students (Talaván, 2012, p. 24).

Therefore, the inclusion of audiovisual translation responses to two major principles, namely, the communication principle -learning is promoted by activities involving real communication- and the meaningfulness principle -learning through activities including language which is meaningful for the student.

Moving towards the social level, Díaz-Cintas (2012) claims that not only do subtitles help learners understand dialogues in a language that is partly unknown, but they also reinforce the knowledge of the viewer's mother tongue. As a result, literacy in 
the language itself is another one among other added values of subtitles, which can also promote the habit of reading, in a playful way, among children.

Besides, audiovisual materials nowadays give students the possibility to work with different combinations of languages and subtitles, depending on their desired goal. In this way, they are also given the possibility to exploit these materials both inside and outside the classroom. In this respect, they shall become conscious of their process of learning, thus developing an autonomous learning.

Following this, it is necessary to highlight that all these arguments have been proved by means of the didactic unit put into practice within the classroom (please, see section 2.8).

\subsection{Types of subtitling}

The different types of subtitles serve various purposes and, although some of them have proved to be useful in a pedagogical sense, some others are still under study. Following Díaz-Cintas (2012) and Talaván (2011), five different types of subtitling may be distinguished, namely:

1. Bilingual subtitles: as its name suggests, they refer to those subtitles in which the oral message appears in one language and the written language is showed in this language and a different one. They can usually be found in certain multilingual countries as well as in international film festivals. However, its pedagogical benefits are still to be shown.

2. Intralinguistic subtitles in the L1: needless to say, this type of subtitling, which was originally created to benefit deaf and hearing impaired spectators, refers to those cases in which both the dialogues and the subtitles appear in the mother tongue. It is also known as captioning and because of the pressure put on certain television channels, they are gaining ground so as to avoid discrimination towards hearing impaired people.

In terms pedagogical benefits, this type of subtitles becomes extremely useful for learners to expand their knowledge and lexical background in their mother tongue, which is necessary to be able to master a foreign language. To put it more simply, it is contributing to develop literacy in the L1.

3. Intralinguistic subtitles in the L2 or bimodal subtitles: Díaz-Cintas (2012, p. 101) and Talaván (2011, p. 268) define bimodal subtitles as those which have been used for foreign language learning along the years and which present the oral and written language in the L2. Because of this, a great amount of researchers have conducted studies to analyse their potential within the language classroom. However, despite the fact that its potential within the classroom has proved to be useful in terms of oral comprehension and enlargement of the lexicon, lower-level students may not benefit from this type of subtitles, since, in some cases, they are not capable of reading the $L 2$ at great speed.

As a result, it is essential to bear in mind that they should be employed with higher-level students, since they would certainly have positive effects for their language learning process: They would discover how different concepts are pronounced as well as the importance of intonation and they would see expressions and new vocabulary in real contexts of use.

4. Traditional interlinguistic subtitles: Being the most common type of subtitles, Díaz-Cintas (2012, p. 99) defines them as those subtitles in which the audio is spoken in the L2 and the written message is included in the L1. Needless to say, these subtitles become crucial for the understanding of the message that is being given.

These subtitles entail a wide range of pedagogical benefits for students: when using them, students can establish connections between the L1 and the L2; they learn both languages in comparison and reflect upon how these languages differ; they can 
connect their culture with the one behind the language they are learning; and, therefore, they shall develop conscious and autonomous learning.

5. Inverse interlinguistic subtitles: Contrary to the previous ones, in this case, the oral message is spoken in the L1 and written subtitles appear in the L2. This combination is not so commonly found outside the language classroom. However, in this context is widely implemented to, once again, compare languages and establish connections.

Although its pedagogical potential has been already mentioned, it is worth noting what Díaz-Cintas (2012, p. 100) states, since he considers that this type of subtitles is detrimental for oral comprehension skills in that students cannot listen to it in the L2. Nonetheless, these subtitles contribute to the acquisition of new vocabulary in the L2.

Apart from that, Talaván (2011, p. 273) considers that, despite the fact that these subtitles may seem to be of little usefulness for foreign language learning, they possess a pedagogical potential much greater than expected, especially for the development of reading skills and vocabulary acquisition. Furthermore, if combined with appropriate activities and tasks, they may also prove to be suitable for the enhancement of other skills of language.

As one can infer from the implementation of the didactic unit (please, see section 2.8) not only do the combination of subtitles when watching a video facilitate the language learning process, but it also contributes to the increase of the students' confidence in their previous knowledge and capacities.

Having discussed all the differences between the various types of subtitles that exist, and having discovered their pedagogical potential for the language classroom, we may confidently say that positive benefits for learners far outweigh the negative effects that both intra and interlinguistic subtitles can bring about.

To this respect, Díaz-Cintas (2012) considers that subtitles in general seem to have the advantage of motivating people -who are not usually keen on reading-to read by employing typical products of the popular culture, such as movies and television series. Reading, therefore, becomes an automatic reflection which the viewer faces daily and which leads to encourage the habit of reading in a natural and immediate environment (Díaz-Cintas, 2012, p. 103).

\subsection{Assets and pitfalls of subtitling within the classroom}

There are no perfect educational resources since all of them present limitations. Consequently, a detailed list of the advantages and limitations that subtitling entail shall be provided below. To this respect, we shall follow the classification given by Talaván (2012, p. 32-35).

1. The use of sutbtitles in audiovisual materials increases the connection between image and audio, since it also includes written text. Therefore, students receive information through different channels, they establish visual associations in their memory and they benefit from translation. To put it more simply, language acquisition is facilitated by means of these associations.

2. According to Gómez (2003, p. 162), its use enhances the ability to recognize words, since those students who use materials with subtitles have shown a significant development of production and recognition of words, oral comprehension, reading skills, decoding of skills and, above all, motivation to read.

3. Not only do subtitles help improve oral skills, but they are also beneficial for the enhancement of writing skills: there is a close relationship between writing and speaking. In fact, we may say that there are few, if any absolute differences between speech and writing.

4. Written support turns video watching into a more meaningful and genuine experience. Since students have to keep up with both the reading and listening pace, students can learn to process the language at great speed. As Gómez 
(2003) claims, the inclusion of subtitles also allows learners to follow the storyline more easily, thus favouring motivation, engagement and interest.

5. The inclusion of subtitles, and, consequently, of audiovisual materials may make students go beyond the walls of the classroom, since their motivation may lead them to watch films and/or series in original version with subtitles at home. In this way, its use can encourage its projection outside the academic environment and shall result, undoubtedly, in the development of life-long learning.

On a different level, we should now mention Talaván's classification (2012) of subtitles limitations.

1. There are different authors who believe that the inclusion of subtitles within the classroom can create a cognitive overload for students which would make of the connection previously mentioned an inconvenience for language learning.

Nevertheless, this statement obliterates the aforementioned Cognitive Theory of Multimedia Learning (Mayer, 2005) and, besides, as Talaván (2012) argues, does not fit into the current digital society where we live and where the population, especially the new generations, is becoming increasingly acquainted with receiving information through various types of channels simultaneously.

Consequently, therefore, the fact that the same information comes from three channels at the same time (visual, oral and written) does not imply any problem or inconvenience for students but it is rather conventional.

2. When they are present, subtitles are read. That is to say, even if someone does not need written support to understand a message, s/he shall read the text if it is given to them. In this way, students are not forced to put all their cognitive resources to use, but they simply read because it is easier and saf er.

Notwithstanding, as Talaván (2012) suggests, this fact can be overcome if teachers devise tasks where subtitles are progressively included. Thus, students shall try to take risks and guess how to translate different expressions and vocabulary, and they shall also acquire the exact and specific translation for them. Likewise, this absence of subtitles in the first stage shall lead learners to pay careful attention to pronunciation.

3. Finally, Talaván (2012) mentions the importance of instructions: without proper preparation stages or instructions, students tend to stop listening to oral information and focus only on reading subtitles -as have been previously mentioned-. It is easier to read a message instead of trying to understand it without reading what is certainly said.

However, by establishing tasks in which students shall use subtitles to achieve specific goals, this can be minimised. Indeed, if teachers devise tasks in which students are forced to pay attention to both the written and the oral channel simultaneously, they shall learn how to read and listen at the same time and for specific purposes (Talaván, 2012).

To conclude, it must be mentioned that audiovisual materials at our disposal are countless and their access is widely available through dif ferent sources: TV, computers, online platforms, or websites, to name but a few. As a consequence, it would make no sense to prevent our students from making use of all these authentic resources where language can be learnt in real contexts of use.

\subsection{Various resources for subtitling}

Subtitling offers a tool to flip traditional classroom dynamics. Consequently, it is necessary to be flexible enough to adapt our audiovisual materials depending on our students' needs and potential, so as to make lessons motivating and engaging. Following this, different websites and activities shall be highlighted, to showcase the potential of this resource within the classroom.

Speak Up, Lingual.Net. or Diviértete con el inglés (El País newspaper): Talaván (2011, p. 266) defines it as a well-known DVD collection from the RBA publishing house 
oriented to L2 English students. This collection was first released in 1985 and it started being commercialised as VHS tapes and, later, as DVD, including up-to-date films with bimodal or intralinguistic subtitles -i.e. with both the written and the oral message in English-, a guide with several lexical elements which may prove intricate to understand for L2 learners, a magazine written in English and a CD with English audios related to the plot of films or any other current issues dealing with it.

Needless to say, all these materials offer a great range of resources to design suitable tasks depending on the language level of students. In this way, teachers are given the possibility to increase students' participation and engagement within the language classroom, which, at any rate, constitutes the backbone for the development of life-long learning.

Lingual.Net. Learning English Through Movies (www.lingual.net/lingualproductitems). This website is defined by Talaván (2011) as oriented to helping students learn a language through movies -obviously enough, it offersnew and motivating ways to produce learning-. To this aim, it offers different actual short films classified depending on the genre: cartoons, cinema, poetry, documentaries, adverts, homemade videos or trips.

In this website users can find guidelines where the suggestions are to watch the video twice: once with bimodal subtitles and another time without subtitles. From that we can infer that, using this technique, learners become familiar with new concepts and their pronunciation and, as a result, their oral comprehension skills are improved, together with their lexical knowledge.

Furthermore, according to Talaván (2011, p. 267), what strikes the most is the fact that certain scenes include an oral comprehension test to check the level of understanding. Consequently, students need to be focus on the information that they are receiving if they want complete the test successfully. As a consequence, the inclusion of these comprehension tests shall force students to put all their cognitive resources to use and shall bring some kind of positive anxiety.

The newspaper El País, which, alongside the well-known company Disney, released several DVD collections called Diviértete con el Inglés including Disney classics in original version with subtitles. Following Talaván (2011), we may infer that their objective was for the young to get acquainted with English in a more-than-fun way, since Disney classics are known to everyone. Together with these DVDs, these collections also offered vocabulary guides.

It is also worth mentioning the role of different subtitling programmes that can be downloaded and used within the language classroom. Obviously enough, these programmes give us the opportunity to actively involve our students in their learning process while learning the dynamics of subtitling and reflecting on the difficulties that this task entails.

Likewise, by making students include subtitles in current and up-to-date videos of interest to our students, they would have a central and fundamental role in their learning process and they would use and acquire new vocabulary for real needs. They would also be comparing the functioning of the two languages and would see the differences between them.

To this respect, one of the programmes that gives us the possibility to work with subtitles is Aegisub, which, as defined in its website, constitutes a free, cross-platform open source tool for the creation and modification of subtitles. Aegisub, therefore, "makes it quick and easy to time subtitles to audio, and features many powerful tools for styling them, including a built-in real-time video preview" (taken from http://www.aegisub.org/). As we shall see in the forthcoming section, this has been the programme implemented within our didactic unit and it has provided students with very useful information and better knowledge of subtitles. Furthermore, it has facilitated the learning of the language and the improvement of the students' results.

On the basis of the above, subtitles, consequently, play a crucial role for the language learning and teaching process and they are already present among different 
famous websites and publishing houses of renown, which suggests and guarantees that, undoubtedly, this resource benefits second language students.

\subsection{Subtitling within the classroom}

So as to verify the potential of subtitles, the following unit, divided into 4 sessions of 125 minutes, approximately, was implemented with a group of 25 students -12 women and 13 men- of C1 level.

\section{SESSION 1}

The first activity of this session was a warm up in which students in pairs were given the titles of different crime and drama films in English and they thought about their translation. After some time, they saw the actual translation and compared with theirs. This way, they reflected upon the differences when translating, which accounts for both syntax and vocabulary, but also culture.

On the basis of this warm up, students took active part in a discussion in which they commented on the previous impressions about the translation of films. After that, each corner of the classroom referred to one crime series and a maximum of 4 students went to each corner depending on their preferences. Once in that corner, they explained why they chose the series and why they liked it.

Then, students participated in a running dictation: in pairs, one person memorised the information from a text about differences between Spanish and English and ran to tell their partner, who had to write it as correctly as possible. This process was repeated as many times as needed. The first pair in finishing the dictation was the winner.

Having finished the dictation and the correction, students created an infographic about these differences and presented it to the class, who voted for the best.

\section{SESSION 2}

The second session started with a brainstorming to get students down to talk about drama and crime series and films and what makes them successful.

The next stage of the lesson was oriented to vocabulary and idioms. After acquiring this new vocabulary and idioms students watched the youtube video "Top 10 Pilot Episodes of TV Dramas" talking about different well-known series and they had to skim and scan information twice: the first time with bimodal subtitles, and the second time without them.

On the basis of the af orementioned subtitles, students reflected on the usefulness of the latter by taking part in a group discussion. With this activity, students were able to check that their comprehension was higher and their vocabulary was more easily acquired when using subtitles.

\section{SESSION 3}

In the third session, students watched the youtube video "The importance of subtitles in education", again, once with bimodal subtitles and once without them. This video worked as an introduction for the next reading activity in which students discovered the different types of subtitles that exist and shared their impressions. On the basis of this reading activity, students created an interactive mind map including the main ideas to summarise the different types of subtitles.

It goes without saying that all the previous activities made students broaden their minds about the benef its of subtitles and discover new data about them to start practicing including subtitles in a video.

Following this, students watched a mute video about Sherlock Holmes and in groups, imagined what the characters were saying, which increased students' creative thinking and imagination. Once they imagined the dialogues, they included them in the video with the programme Aegisub and discovered the difficulties when inserting subtitles. 
Finally, students compared how different groups had subtitled the video and this way, they reflected on the use of the language, and learnt and refreshed some vocabulary and grammatical structures used by other groups.

SESSION 4

This session was devoted to the final project, which was the subtitling of an episode of The Sinner.

Before going any further, it is necessary to mention the rationale of the selection of this series and, more specifically, of this episode. Needless to say, the exposure to English in real contexts of use is more than appropriate to improve this language. In this regard, the vocabulary and accent used in this episode was clear enough to be understood by the students and it also dealt with the topic of crime and punishment, which was studied throughout the unit.

Besides, this episode left room for the development of creativity and imagination, since it presented some facts that could not be completely understood without watching the whole series. Consequently, it was a good way to get our students hooked on the series after working on it.

To start with, students created a group story from different photos and posted it in a Padlet, so as to predict information and put all their cognitive resources to use.

With the help of this warm-up students started with the project. In the same groups, they subtitled part of the first episode of the crime series "The Sinner". With such a view, they used the programme introduced in the previous session, that is, Aegisub, and they included approximately 10 minutes of traditional interlinguistic subtitles in Spanish. In this way, they translated and used the vocabulary and grammar (previously) learnt.

After that, students reflected upon the main difficulties they found when translating and share them with their classmates.

To finish this lesson, and consequently, this unit, students individually completed an online questionnaire to assess the different tasks, techniques and activities, their usefulness and their degree of motivation and engagement.

Needless to say, this unit exposes the possibilities of subtitles within the language classroom and, more specifically, the advantages for learning the language.

\section{RESULTS}

So as to analyse the potential and extent of success of subtitles within the classroom, we evaluated the results of the test that took place before this unit and the result of the test that was completed after it.

In comparison with the results of the test prior to the unit, and taking into account the results of the test that took place after the unit, we must state that, after this unit, $100 \%$ of students passed the speaking and reading part with better results; $95 \%$ of the students improved their writing skills and $90 \%$ improved their listening results. Therefore, the previous unit has showcased the myriad of benefits surrounding audiovisual translation and audiovisual materials and subtitles within the language classroom.

Following this, we may confidently say that not only did audiovisual translation results in an enhancement of writing and reading skills, but it also resulted in the improvement of listening and speaking abilities. Subtitling, therefore is advantageous for all the dimensions of communication: it benefits the development of both productive and receptive skills of language.

Consequently, translation, in this regard, has benefited learners for it has facilitated the establishment of appropriate connections between the L1 and the L2. As 
such, translation helps learners recognise errors due to interference and take advantage of the positive transfer ensuing from the employment of one's own language.

\section{CONCLUSIONS}

The prior results bring to light the wide range of assets that this research and didactic unit have proved to entail. In our globalizing and digital world, students perform translation very frequently since it can come up in all types of daily contexts and communication is more frequently taking place through technology. Therefore, making it explicit, the implementation of translation and, more specifically, audiovisual translation, within the foreign language classroom has improved learners' understanding of it as a procedure to facilitate communication, which, at any rate, constitutes the backbone of all language teaching methodology.

Following this, audiovisual translation has provided students with the possibility of learning to learn and acknowledging the intricate process that they must carry out to perform it successfully and constitutes a bridge to connect languages and cultures.

Nevertheless, it is also worth noting that this research has also set out those limitations that must be taken into consideration so as to make the implementation of audiovisual materials, subtitles and translation activities successful within the classroom.

To finish, it must be highlighted that translation offers teachers the opportunity to implement appealing activities with a view to drawing learners' attention to the new language they are learning, and to make them feel engaged with the work they are doing.

\section{BIBLIOGRAPHICAL REFERENCES}

Baker, M. (2001). Routledge Encyclopedia of Translation Studies. London: Routledge.

Cook, G. (2012). Translation in Language Teaching: an Argument for Reassessment. Oxford: Oxford University Press.

Council of Europe. (2001). Common European Framework of Reference for Languages: Learning, Teaching, Assessment. Cambridge: Cambridge University Press.

De Arriba García, C. (1996). Introducción a la Traducción Pedagógica. Barcelona: Universidad de Barcelona.

Díaz-Cintas, J. (2012). Los subtítulos y la subtitulación en la clase de lengua extranjera Abehache, 3, 95-114.

Gómez, M. (2003). Un modelo de aprendizaje: La televisión por satélite para la elaboración de planes de clases en la enseñanza del inglés. Anales de la Universidad Metropolitana, 3(2), 159-169.

Ivarsson, J. And M. Carroll. (1998). Subtitling. Simrishamn: TransEdit HB.

Krashen, S. (1985). The Input Hypothesis: Issues and Implications. Essex: Longman.

Krashen, S. (1987). Principles and Practice in Second Language Acquisition. London: Prentice-Hall International.

Lertola, J. (2015). Subtitling in Language Teaching: Suggestions for Language Teachers.

Retrieved

from https://www.researchgate.net/publication/270893736_Subtitling_in_Language_ Teaching_Suggestions_for_Language_Teachers 15/06/2020.

Lertola, J. (2019). Audiovisual translation in the foreign language classroom: applications in the teaching of English and other foreign languages. Retrieved from https://files.eric.ed.gov/fulltext/ED593736.pdf 18/08/2020. 
Mayer, R. E. (2005). Cognitive Theory of MultimediaLearning. In R. E. Mayer (Eds.), The Cambridge handbook of multimedia learning. Cambridge University Press, 3148.

Paivio, A. and J. Clark. (1991). Dual Coding Theory and Education. Educational Psychology Review, 3(3), 149-210.

Pintado Gutiérrez, L. (2012). Fundamentos de la traducción pedagógica: traducción, pedagogía y comunicación. Sendebar, 23, 321-353.

Soler Pardo, B. (2017). La traducción audiovisual en la enseñanza de una LE: la subtitulación como herramienta metodológica para la adquisición de léxico. Tejuelo, 26, 163-192.

Talaván Zanón, N. (2011). La influencia efectiva de los subtítulos en el aprendizaje de lenguas extranjeras: análisis de investigaciones previas. Sendebar, 22, 265-282.

Talaván Zanón, N. (2012). Justificación teórico-práctica del uso de los subtítulos en la enseñanza-aprendizaje de lenguas extranjeras. TRANS. Revista de Traductología, O(16), 23-37. Retrieved from http://dx.doi.org/10.24310/TRANS.2012.v0i16.3209 21/02/2020.

Wang, Y. and C. Shen. (2007). Tentative model of integrating authentic captioned video to facilitate ESL learning. Sino-US English Teaching, 4(9). Retrieved from https://www.researchgate.net/publication/255488073_Tentative_model_of_integ rating_authentic_captioned_video_to_facilitate_ESL_learning 20/06/2020. 